\title{
V+HOP Combo: approach to increase students' performance in Science VI
}

\author{
V+HOP Combo: enfoque para aumentar el rendimiento de los estudiantes en Ciencias VI \\ Combo V+HOP: abordagem para aumentar o desempenho dos alunos em Ciências VI
}

\author{
Gringo C. Ote \\ gringo.ote@deped.gov.ph \\ Jose Rizal Elementary School, Jose Rizal, Sta. Cruz, Davao del Sur \\ https://orcid.org/0000-0002-7422-861X
}

Jannith O. Guardian

jannith.guardian@ deped.gov.ph Jose Rizal Elementary School, Jose Rizal, Sta. Cruz, Davao del Sur https://orcid.org/0000-0002-3203-5641

\begin{abstract}
The improvement of students' performance has become an increasing priority for teachers over the last decade. Hence, the focus should be directed to the development of integrated, generalizable, and transferable skills among our learners. The purpose of this study is to enhance the students' performance in Science VI using the V+HOP Combo (Video-aided instruction, Hands-On, and Peer learning). A descriptive research design was used in this study to determine the effect of the intervention on the academic performance of the participants who were the 10 Grade Six pupils of Jose Rizal Elementary School enrolled in the School Year 2020-2021 who got an average of 79 and below from the first quarter to the third quarter. Results of the pretest and posttest were used to determine if there is a significant difference in their performance. The test of difference or $t$-test showed that utilizing of $\mathrm{V}+\mathrm{HOP}$ Combo significantly improved the scores of the students. This proves that the strategy is effective and helpful in enhancing the academic performance of the learners involved in this study. Consequently, it is recommended to schools and teachers the use of V+HOP Combo to increase and enhance the students' performance in all subject areas. Also, researchers are encouraged to explore other strategies that could be integrated into the V+HOP COMBO to further increase its efficacy in boosting student performance.
\end{abstract}

Keywords: Academic Performance, Video-Aided instruction, Hands-On Instruction, Peer Learning

\section{RESUMEN}

La mejora del desempeño de los estudiantes se ha convertido en una prioridad cada vez mayor para los docentes durante la última década. Por lo tanto, el enfoque debe dirigirse al desarrollo de habilidades integradas, generalizables y transferibles entre nuestros alumnos. El propósito de este estudio es mejorar el desempeño de los estudiantes en Ciencias VI usando el Combo V+HOP (instrucción asistida por video, práctica y aprendizaje entre pares). En este estudio se utilizó un diseño de investigación descriptivo para determinar el efecto de la intervención en el rendimiento académico de los participantes que fueron los 10 alumnos de Sexto Grado de la Escuela Primaria José Rizal matriculados en el Ciclo Escolar 2020-2021 que obtuvieron un promedio de 79 y abajo del primer trimestre al tercer trimestre. Los resultados del pretest y postest se utilizaron para determinar si existe una diferencia significativa en su desempeño. La prueba de diferencia o prueba t mostró que la utilización de V+HOP Combo mejoró significativamente las puntuaciones de los estudiantes. Esto demuestra que la estrategia es efectiva y útil para mejorar el desempeño académico de los estudiantes involucrados en este estudio. En consecuencia, se recomienda a las escuelas y profesores el uso de V+HOP Combo para aumentar y mejorar el rendimiento de los estudiantes en todas las materias. Además, se alienta a los investigadores a explorar otras estrategias que podrían integrarse en el V+HOP COMBO para aumentar aún más su eficacia para mejorar el rendimiento de los estudiantes.

Palabras clave: Desempeño académico, Instrucción asistida por video, Instrucción práctica, Aprendizaje entre pares

\section{RESUMO}

A melhoria do desempenho dos alunos tornou-se uma prioridade crescente para os professores na última década. Assim, o foco deve ser direcionado para o desenvolvimento de habilidades integradas, generalizáveis e transferíveis entre nossos alunos. O objetivo deste estudo é melhorar o desempenho dos alunos em Ciências VI usando o V+HOP Combo (instrução assistida por vídeo, hands-on e aprendizagem por pares). Um desenho de pesquisa descritivo foi usado neste estudo para determinar o efeito da intervenção no desempenho acadêmico dos participantes que eram os 10 alunos do 
sexto ano da escola primária Jose Rizal matriculados no ano letivo 2020-2021 que obtiveram uma média de 79 e abaixo do primeiro trimestre para o terceiro trimestre. Os resultados do pré-teste e pós-teste foram usados para determinar se há uma diferença significativa em seu desempenho. O teste de diferença ou teste $t$ mostrou que a utilização do $\mathrm{V}+\mathrm{HOP}$ Combo melhorou significativamente os escores dos alunos. Isso comprova que a estratégia é eficaz e útil para melhorar o desempenho acadêmico dos alunos envolvidos neste estudo. Consequentemente, recomenda-se às escolas e professores o uso do V+HOP Combo para aumentar e melhorar o desempenho dos alunos em todas as disciplinas. Além disso, os pesquisadores são incentivados a explorar outras estratégias que possam ser integradas ao V+HOP COMBO para aumentar ainda mais sua eficácia no aumento do desempenho dos alunos.

Palavras-chave: Desempenho Acadêmico, Instrução Assistida por Vídeo, Instrução Prática, Aprendizagem por Pares

\section{INTRODUCTION}

The improvement of students' performance has become an increasing priority for teachers for decades now. This led to the establishment of focus on developing integrated, generalizable, and transferable skills among our learners which will equip them to cope with contemporary demands and build within them a foundation for lifelong learning.

Needless to say, students' performance measures what a learner is expected to know, be able to do and understand at the end of a learning process or sequence (Lassnigg, 2012). The way such outcomes are defined and written guides our teaching and learning process and influence the quality and relevance of education and training. Learning outcomes matters to individual learners, the labor market, and society.

We, as teachers are regarded as the agents who can significantly contribute to the enhancement of the quality of education and consequently to the attainment of the avowed educational goals and the desirable students' learning outcomes (Maligalig \& Albert, 2012). Our potential as teachers to influence the success of any educational effort stems from our role as the direct participants in the educational process. We are always at the forefront in providing activities that could help enhance our students' learning. We are the ones providing our students the opportunities to develop skills that they need to thrive in the future. Hence, under this professional role, we can help make education more efficient and effective.

In the Division of Davao Del Sur, particularly in Jose Rizal Elementary School, Santa Cruz North District, there has been a perennial problem in the classes that I have taught and that is the low performance of students in Science VI. I am extremely concerned about this condition because I know that it is very important that my learners will be able to acquire the competencies expected of them by the end of each quarter. Sadly, almost all of my pupils performed poorly, and they could not reliably demonstrate the skills expected of them and that prompted me to think about intervention and come up with one as soon as possible. Together with my colleagues, we crafted a strategy to improve my learners' performance by combining strategies that worked well in our individual practice. We believed that as teachers we should be creative and resourceful if we want to be catalysts of change and improve the learning ability of our students.

With the challenge I encountered as a teacher and the difficulty faced by my learners, we decided to implement an intervention that would upgrade students' performance in Science VI through combining Video-aided instruction, Hands-On, and Peer learning (V+HOP Combo).

$\mathrm{V}+\mathrm{HOP}$ Combo is a blended approach utilizing video-aided instruction, hands-on learning, and peer learning where the teacher will use different strategies to stimulate the students. One approach is through the use of educational videos for the lessons to provide visual stimuli to the students. In the study conducted in Taiwan by Chen and colleagues (2021) on the Effects of a Video Featuring Connected Speech Instruction on EFL Undergraduates in Taiwan, they found out that such instruction was significantly effective for improving the English language learners' connected speech skills. They also noted positive results in the outcomes of the questionnaires, showing significantly enhanced learning attitudes to English speaking (Chen, Y. Y., Chang, Y. S., Lee, J. Y., \& Lin, M. H., 2021). Furthermore, Atkinson and Hansen (2017) conducted a study that 
revealed that an increase in the student's performance could be achieved if the teachers provide videos that will aid the students learning because this will catch learners' attention.

Next, students will be given hands-on activities based on the tasks indicated in the exemplar. Hands-on instruction is learning by doing. Pedroso, J. E. P. (2021) espoused in his findings when he conducted his study on School On Wheels and Multimedia-Aided Instructions as Mediators of Students' Local Cultural Heritage Awareness" that students' knowledge is improving via teaching and learning activities that give experiential and meaningful learning (Pedroso, J. E. P., 2021). Bilgin (2016) also opined that Hands-on learning fosters students' minds to grow and learn based on the experience and the environment they are exposed to.

The next step on the intervention is Peer Learning where the learners will be placed in a group where he has to collaborate to engage with other learners to perform tasks and learn concepts. In education, peer learning has a significant impact on deeper learning and is considered an effective method of collaborative and deeper learning (Hamad, S. M. S., Iqbal, S., Alothri, A. M., Alghamadi, M. A. A., \& Elhelow, M. K. K. A. (2020). They further claimed that the peer learning style provides an opportunity for students to share thoughts and emotional reactions freely which helps to reduce stress and develop resilience. The feeling of staying connected with peers during the sessions significantly augmented the ability to combat the academic challenge and augment social interactions. In support, Ogundola (2016) posited that Peer Learning instigates knowledge and skill acquisition through active helping and support among peers.

In a nutshell, showing the learner's videos that illustrates and explains the subject matter, giving them the chance to experience and manipulate objects while doing tasks, as well as encouraging them to interact with their peers are ways to make sure that they have viable building blocks that would facilitate their learning, gearing to amplify their performance (Chaudari, 2017).

\section{Statement of the Problem}

This study sought to answer the question: "Will V+HOP Combo as an intervention increase the performance of Grade Six learners in Science VI?"

\section{THEORETICAL FOUNDATION}

This study is anchored on the theory posited by Howard Gardner (1983) on Multiple Intelligences. He claimed that people have eight independent ways of processing information, which are: Verbal-Linguistic (Word Smart), Logical-Mathematical (Logic Smart), Visual-Spatial (Picture Smart), Auditory-Musical (Music Smart), Bodily-Kinesthetic (Body Smart), Interpersonal (People Smart), Intrapersonal (Self Smart), and Naturalistic (Nature Smart). However, Gardner emphasized that it's more accurate to think of the eight intelligences as abilities or strengths as the human brain proved to be extremely complex, and all these types of "smarts" work together.

Similarly, like the Multiple Intelligences Theory, the Learning Styles Theory of Daniel T. Willingham (2018) focuses on the ways we perceive information. The learning styles he proposed to focus on how we process information using our senses. His theory involves three learning styles which are auditory (hearing), visual (seeing), and tactile/kinesthetic (touching and moving). For him, learners most often prefer one style over the others. As a result, there are what we call as Visual learners, who learn best by using images, graphs, maps, and drawings as well as Auditory learners, who prefer to learn by hearing and speaking information. There are also Tactile/ Kinesthetic learners, who learn best by experiencing, touching, and performing tasks. With this theory in mind, it makes sense that children who have a specific learning style can learn more effectively if they use their preferred style more often. However, no one has exclusively one single style or preference, consequently, learners all use three methods to receive information even if one receiving style may be dominant. 
One of the studies conducted on exploring learning style and multiple intelligence was dome by Sener, S., \& Çokçaliskan, A. (2018). They believed that it is very important for teachers to understand their learners' learning styles and multiple intelligences since they can carefully identify their goals and design activities that can teach to the different intelligences, and design studentcentered activities. The result revealed that their respondents had almost all these types of learning styles but mostly they were found to be tactile and auditory learners. Moreover, the three intelligence groups: Naturalistic, Visual and Kinesthetic intelligences types received the highest score. Upon analyses, the significant difference between the learning styles and multiple intelligences of males and females was evident. Also, it was indicated that there was a positive correlation between the two variables.

Another significant study focusing on student performance was conducted by Winarti, A., Yuanita, L., \& Nur, M. (2019). They were concerned about the low attention teachers give on students' potential compared to academic ability. Oftentimes, teachers' focus on academic ability as the sole determinant of successful learning which resulted to failure to develop the students' potential called Multiple Intelligences (MI). To overcome that issue, they developed a teaching strategy based on Multiple Intelligences in delivering their science lessons. The results revealed that the Multiple Intelligences strategy has an effect on and can be a significant predictor of the development of students' Multiple intelligences. Moreover, after the intervention, an improvement on the Science Process Skills Test result showed an improvement, specifically in the questioning ability.

\section{METHODOLOGICAL PROCEDURES}

This chapter presents the design, sampling method, instrument, procedures and data analysis of the study.

\subsection{Research Design}

This study is quantitative in design and descriptive in presentation as well as in the analysis of data. Descriptive research is a quantitative research method that attempts to collect quantifiable information for statistical analysis of the population sample (Bloomfield, J., and Fisher, M. (2019). The information we are seeking in this study is the change in the performance of the students in Science 6 after the intervention program to verify and validate its effectiveness.

\subsection{Respondents and Sampling}

The sampling procedure used in this study is purposive sampling. Also called as judgment sampling, purposive sampling is a technique used to deliberately choose participants based on the qualities the participant possesses (Etikan, I., Musa, S.A. \& Alkassim, R.S., 2016). It is a nonrandom sampling technique that does not require underlying theories or a set number of participants. To put it simply, the researchers decided what needs to be known and sets out to find the respondents, in this case our students, who can and are willing to provide the information by virtue of knowledge or experience.

This study was conducted in Jose Rizal Elementary School of Sta. Cruz North District, Division of Davao del Sur. The participants of this study were the ten grade six learners of section Sapphire. The researchers used the purposive sampling method to determine the participants. To identify the participants, the learner should have an average of 79 or below in Science VI from the first quarter up to the third quarter of this school year. These students were enrolled in Jose Rizal Elementary School. Gender and age of the participants were varied and not part of the inclusion criteria we have set. 
In order to adhere with the ethical standards in research, their identities were not revealed to the public nor mentioned in this study for security purposes. Also, all these students were consented by parents to participate in the intervention process that lasted for five weeks.

\subsection{Research Instrument}

The researcher utilized a validated test in Science 6 developed by the researcher. It was a 40 item test covering 2 competencies that would be measured after the intervention. This instrument was used as pre-test and post-test questionnaire. For the qualitative data, an interview was conducted by the researchers to verify results and gather information on the impact of the intervention on the learners.

\subsection{Data Gathering Procedure}

The conduct of this research followed the necessary protocols and these were the following steps:

Before starting any procedure, as researchers, we asked for an endorsement from the School Principal and District Supervisor to conduct the study.

Next, the questionnaires that were used as pretest and posttest instruments were submitted to a group of Master Teachers, who are considered experts in the field, for validation. After they have made their corrections and gave their suggestions, we edited the questionnaires and re-submitted them for the second round of validation. Immediately after the experts evaluated the questionnaires as valid, we started the next step.

To establish instrument validity for this study, we conducted pilot testing on a group of grade six students from the nearby school in the same district with similar abilities to the population we identified as our respondents.

Results of the pilot testing were subjected to item analysis to determine items to be included in the final test instrument. Results of the pilot testing were subjected to statistical treatment using Cronbach alpha which yielded a reliability of 0.81 . This implies that the test is reliable since it is within the range of 0.70 to 1.00 .

After the reliability was established, the District Research Committee gave us the go-signal to reproduce the questionnaires. After revisions, adequate and clear copies were printed to avoid problems with the administration.

With the approval of the questionnaire, we wrote a letter and sent it to the District Supervisor, School Head, and Barangay Captain to gain permission to conduct the study. Health and safety protocols like wearing a face mask, face shield, and social distancing were strictly observed during the conduct of the intervention.

Also, written consent was signed by the guardians of the participants allowing them to be part of the study. As indicated in the consent form, the participants have the right to withdraw from the study once they feel discomfort. We are serious about keeping all the participants' information to protect them and to prevent issues.

We administered the pretest to the 10 grade six learners in the first stage of the implementation of the intervention. The data were considered as a baseline and were used later for comparison. Immediately after the pretest, the activities indicated in the matrix were followed.

The study covered the Most Essential Learning Competencies (MELC) in Science VI specified under the fourth quarter. The timeline/ matrix presented in the next page was observed: 
Table 1. Matrix of Activities

\begin{tabular}{|c|c|c|c|}
\hline DATE & $\begin{array}{c}\text { ACTIVITY } \\
\text { TITLE }\end{array}$ & LESSON & TASK/ ACTIVITY \\
\hline $\begin{array}{l}\text { Week } 1 \\
\text { June 07- } \\
11,2021\end{array}$ & $\begin{array}{l}\text { Watch, Play } \\
\text { and Lets } \\
\text { Cooperate }\end{array}$ & $\begin{array}{l}\text { - What is an Earthquake? } \\
\text { - Video: "The Philippines... In } \\
\text { the Ring of Fire" } \\
\text { - https://www.youtube.com/watc } \\
\text { h?v=dX5vcCsz0LO } \\
\text { - Kinds of Earthquake. } \\
\text { - Measuring Earthquake }\end{array}$ & $\begin{array}{l}\text { The learners watched the lesson through } \\
\text { a video from the teacher. The discussion } \\
\text { then followed. After which the students } \\
\text { had the hands-on activity by "simulating } \\
\text { the movement of Tectonic Plates". To } \\
\text { deepen the learning of the students, the } \\
\text { students were grouped by two for them } \\
\text { to share their ideas regarding the } \\
\text { simulation. }\end{array}$ \\
\hline $\begin{array}{l}\text { Week } 2 \\
\text { June } 14- \\
18 \\
2021\end{array}$ & $\begin{array}{l}\text { V+HOP } \\
\text { Combo } \\
\text { Behold, } \\
\text { Perform and } \\
\text { Let's have a } \\
\text { pair share }\end{array}$ & $\begin{array}{l}\text { - Volcanoes and the Different } \\
\text { Volcanic Activities. } \\
\text { - https://www.youtube.com/watc } \\
\text { h?v=IAmqsMOG3RM } \\
\text { - Changes on Earth Surface due } \\
\text { to Volcanic Eruptions. } \\
\text { - https://www.youtube.com/watc } \\
\text { h?v=KHJ0sSZA5Vs }\end{array}$ & $\begin{array}{l}\text { The learners watched the lesson through } \\
\text { a video from the teacher. After which the } \\
\text { students had the hands-on activity } \\
\text { "Erupting Diet coke with mentos". To } \\
\text { strengthen the learning, the students were } \\
\text { grouped by two and asked them to } \\
\text { discuss the topic. }\end{array}$ \\
\hline $\begin{array}{l}\text { Week } 3 \\
\text { June 21- } \\
25,2021\end{array}$ & $\begin{array}{l}\text { View, Do and } \\
\text { Let's Learn } \\
\text { Together }\end{array}$ & $\begin{array}{l}\text { - Effects of an Earthquake } \\
\text { - Safety Precautions before, } \\
\text { during, and after an earthquake } \\
\text { - https://www.youtube.com/watch } \\
\text { v=dJpIUrSOFY\&t=158s } \\
\text { - Earthquake Drill }\end{array}$ & $\begin{array}{l}\text { The learners viewed the lesson through a } \\
\text { video from the teacher. After which the } \\
\text { students had the hands-on activity } \\
\text { (simulating the Earthquake). To deepen } \\
\text { the learning, the students were grouped } \\
\text { by two and asked to asked them to } \\
\text { discuss the topic. }\end{array}$ \\
\hline $\begin{array}{l}\text { Week } 4 \\
\text { June } 28- \\
\text { July } 02 \text {, } \\
2021\end{array}$ & $\begin{array}{l}\text { V+HOP } \\
\text { Combo } \\
\text { See, Touch } \\
\text { and Let's } \\
\text { Share }\end{array}$ & $\begin{array}{l}\text { - Plate Boundaries } \\
\text { - Types of Plate Boundaries } \\
\text { - What is Pangaea and Plate } \\
\text { Tectonics? } \\
\text { - https://www.youtube.com/watch } \\
\text { ?v=AqrInJ8 Nes } \\
\text { - "Plate Tectonic for Kids" } \\
\text { www.makesgenius.com } \\
\text { - https://www.youtube.com/watch } \\
\text { ?v=tcPghqnnTVK }\end{array}$ & $\begin{array}{l}\text { The learners watched the lesson through } \\
\text { a video from the teacher. The discussion } \\
\text { then followed. After which the students } \\
\text { had the hands-on activity by simulating } \\
\text { the movement of Tectonic Plates. To } \\
\text { deepen the learning of the students, the } \\
\text { students were grouped by two for them } \\
\text { to share their ideas regarding the } \\
\text { simulation of the activity. }\end{array}$ \\
\hline $\begin{array}{l}\text { Week } 5 \\
\text { July 05- } \\
09,2021\end{array}$ & $\begin{array}{l}\text { Look and } \\
\text { Let's Give } \\
\text { Our Share }\end{array}$ & $\begin{array}{l}\text { - Benefits of Volcanic Eruptions. } \\
\text { - The danger of Volcanic } \\
\text { Eruptions } \\
\text { - Precautionary Measures Before, } \\
\text { During, and After a Volcanic } \\
\text { Eruptions. } \\
\text { - https://www.youtube.com/watch } \\
\text { ?v=ywovuS_4KNk }\end{array}$ & $\begin{array}{l}\text { The learners watched the lesson through } \\
\text { a video from the teacher. Explication of } \\
\text { the topic then followed. After which the } \\
\text { students had the hands-on activity } \\
\text { (simulating the Dangers of Volcanic } \\
\text { Eruptions). To intensify the learning, the } \\
\text { students were grouped by two and asked } \\
\text { to asked them to discuss the topic. }\end{array}$ \\
\hline
\end{tabular}

After five weeks of implementation, we administered the posttest to the 10 grade six students. The results of both pretest and posttests were collated and tabulated before they were 
submitted for statistical treatment. Results were analyzed and interpreted according to the purpose of the study.

\subsection{Data Analysis Plan}

Data were analyzed to determine the effectiveness of the V+HOP Combo using the result of the pretest and posttest to determine if there is a significant difference between the scores of the students before and after the intervention. Though the study lasted only for a month, the data gathered were treated using descriptive statistics which is the Paired t-test and presented in tabular, textual and graphical form. Scores and observation data were also analyzed to determine the performance in Science VI.

\section{RESULTS AND DISCUSSION}

\section{Baseline Observation}

During the conduct of the pre-assessment, we identified 10 pupils who have an average of 79 and below from the first quarter up to the third quarter in Science VI. Aside from the low scores of the identified learners, I also have noticed that they seem to have an aversion to my subject which is Science VI. That alone is enough to cause an alarm on my part as the teacher. With that, I became keener in pursuing this study and for testing if the strategy or the intervention we concocted will be able to bring out the result we desired. The identified learners also expressed eagerness to be a part of something new and novel and that is all the encouragement we need.

\section{During the Implementation of $\mathrm{V}+\mathrm{HOP}$ Combo}

Using the proposed intervention which is the $\mathrm{V}+\mathrm{HOP}$ Combo, we started Day 1 by showing them educational videos related to their lesson. While watching the video, the students were captivated and they enjoyed the experience. We noticed that their interest was piqued and that they seem to be able to understand what the narrator was trying to say though there were a few who displayed confused expressions and we have noted those reactions for reference. It seemed that though they were having fun while watching the video, still some did not grasp the concepts.

After the video presentation, we supplemented the instruction with a hands-on activity. We gave them individual tasks to be performed and questions to be answered. Majority of the participants were engaged because they relished the chance to ponder upon the situation and connect it to the video they have watched.

To deepen their knowledge and sustain their eagerness to learn, we gave them another activity still related to the topic wherein we paired them with their peers. Collaborative efforts inspired by pairing with other learners were evident and it seemed that they performed far better and had a deeper understanding of the concepts being presented.

As we continued with the intervention, we noticed that Pupil \#4 and Pupils \#6 to \#10 were steadily making progress and became more engaged in the activities. However, the performances of Pupils \#1 to \#4 were not excellent as we have desired though they also have shown improvements in their performances. Pupil \#5 started showing significant improvement on the fourth day of the intervention and it was a relief for us. The process indicated in the matrix was followed until week 5 ended.

Overall, based on our objective evaluation, the intervention with its varied strategies was well appreciated by the learners because they believed that the approach enabled them to express their ideas.

"Nalingaw kaayo mi Sir kay daghang mga activities among gibuhat ug nakakat-on mi sa mga lessons pamaagi sa pag tan-aw ug videos ug dili mi maulaw sa pag express sa among ideas". Learner A. 
(We enjoyed it a lot Sir because there are plenty of activities that were were able to perform and we learned the lessons through watching the videos and we were not shy in expressing our ideas.)

"Ing-ani pud unta sa classroom Sir no. Naa untay video pirimi kay makita jud namo ang bulkan ug nganong maglinog". Learner C.

(Hopefully, this will always happen in the classroom Sir. Videos should be shown always so that we can see the volcano and why there's an earthquake.)

\section{Comparison between the Baseline and Post Intervention Performance of the Students}

Post-assessment was conducted after the five-week intervention schedule to determine the effectiveness of the V+HOP Combo in improving the performance of the participants in Science VI. Table 2 on the next page shows that all the scores have increased after the intervention though some showed significant increases, others still have to catch up and reach the passing mark.

The increase in the overall performance of the students could be attributed to the intervention given to them for 5 weeks. The effectiveness of the intervention is supported by Atkinson and Hansen (2017) who conducted a study that revealed that an increase in the student's performance could be achieved if the teachers will provide videos that will aid the students learning because this will catch the attention of learners. This is also aligned with the ideas of Bilgin (2016), who opined that hands-on learning fosters students 'minds to grow and learn based on the experience and the environment they are exposed to. Moreover, the result conforms to Ogundola (2016) who posited that peer learning improves knowledge and skills acquisition of learners.

Table 2. Comparison between Baseline and Post Observation Performance

\begin{tabular}{c|c|c|c}
\hline \multirow{2}{*}{ Participant } & \multicolumn{2}{|c|}{ Scores } & \multirow{2}{*}{ Difference } \\
\cline { 2 - 3 } & Pretest & Posttest & +3 \\
S-1 & 5 & 8 & +2 \\
S-2 & 6 & 8 & +3 \\
S-3 & 8 & 11 & +6 \\
S-4 & 14 & 20 & +3 \\
S-5 & 7 & 10 & +5 \\
S-6 & 16 & 21 & +5 \\
S-7 & 15 & 20 & +7 \\
S-8 & 23 & 30 & +7 \\
S-9 & 20 & 27 & +7 \\
S-10 & 18 & 25 & +48 \\
\hline TOTAL & 132 & 180 & \\
\hline
\end{tabular}

Test on the Significant Difference between the Pre-Test and Post-Test Score.

Table 3 on the next page presents the test of the difference between the pretest and post-test scores of the subjects. Data generated by the software registered a p-value of .001 which is significant. Since the p-value of 0.00 is less than the 0.05 level of significance, this indicates that there is a significant difference between the pretest score and the post test score of the grade six pupils. This implies that the used of V+HOP COMBO has contributed to the students' performance in Science VI. 
Table 3. Test on the Significant Difference between the Pre-Test and Post-Test Score

\begin{tabular}{|c|c|c|c|c|c|c|}
\hline \multirow{2}{*}{$\begin{array}{l}\text { A } \\
\text { Descriptives }\end{array}$} & & & \multicolumn{2}{|r|}{ statistic } & \multirow{2}{*}{$\begin{array}{c}\mathrm{df} \\
9.00\end{array}$} & \multirow{2}{*}{$\begin{array}{c}\mathrm{p} \\
<.001\end{array}$} \\
\hline & B & Student'st & & -7.86 & & \\
\hline & & $\mathrm{N}$ & Mean & Median & SD & $\mathrm{SE}$ \\
\hline $\mathrm{A}$ & & 10 & 13.2 & 14.5 & 6.34 & 2.00 \\
\hline B & & 10 & 18.0 & 20.0 & 8.19 & 2.59 \\
\hline
\end{tabular}

\section{CONCLUSION}

In this research journey, we have learned that V+HOP Combo is a tool that if implemented prudently, could help our students become more proactive and more engaged in their learning. That interest and enthusiasm could push our learners into achieving more and earning higher marks in all their subjects.

Looking at how they were fascinated by what they were seeing on the big screen made me realize that using multimedia is a great tool to concretize concepts to our learnings. As the adage goes, "To see is to believe." If our learners can witness the phenomena we want them to know about, it would be more memorable for them. Visual learners appreciate more strategies that allow them to see images demonstrating the concepts.

If we add into our approach the hands-on tasks/activities that could make the phenomenon more real to them, it would mean deeper learning. Remember our students can learn more by doing and experiencing things for themselves. It would also give them something to do which is what kinesthetic learners require from the experience. The more actively engaged they are, the faster their minds process and absorb the lesson. As what Confucius has said, "I hear and I forget. I see and I remember. I do and I understand". Those timeless words exemplifies the intent as well as the result of this intervention.

Moreover, as we allowed them to talk and collaborate with their peers, the whole subject matter became more fascinating to them. More so when their partners shared their perceptions and interpretation of the facts presented to them, their understanding of the matter being discussed broadened and became enriched. It was quite fascinating to watch the learners actively talking about what they have discovered in a very comfortable manner. It is true that when the spirit of collaboration and cooperation among learners will be developed it would make them more active and self-directed individuals. The opportunity for active participation, clarifying confusion through discussions helped students to continue with the activities with joy.

Furthermore, we have also observed that the V+HOP Combo increased the self-confidence of the learners as it gave them the chance to openly share their views and interact with both their peers and with us, their teachers. Moreover, the V+HOP Combo approach was able to help in reducing the stress level of the learners as the tasks were fun and non-threatening.

On the other hand, the V+HOP Combo especially in its implementation may put pressure on the part of the teachers as they have to prepare more materials compared to just one strategy. The teacher has to assess whether the video fits the level of the students and the instructional hands-on activities should be engaging and relevant to the topic discussed. Further, the peer partner of the student may not be as cooperative as we hope he/she will be and that would create a negative impact on the learner. Nevertheless, if these things will be done and carried out in order, pupils will perform better. Given all that transpired, we believe that it is essential that the teacher should 
believe in the process and the intervention. The teacher should also consider the kind of learners who will undergo the said intervention and tailor fit the implementation to their uniqueness. The constant monitoring of the class performance of the students and the support and concern given by the teacher could make miracles happen.

Though this study is limited in terms of the participants as there are only 10 students that are included because they were the ones who met the inclusion criteria set by the researchers, still, the results were positive and it was appreciated by both the learners and the parents. In terms of scope, this study focused only on the students of one grade level which is Grade 6, one subject area which is Science, and only one school, Jose Rizal Elementary School. Nevertheless, the intervention may be replicated in other schools, in other grade levels and subject areas to determine if it will still work considering other population.

Based on the findings, it is recommended that V+HOP Combo be implemented and replicated by teachers on a bigger group of students who are also having difficulties in their subjects, not only in Science to help validate our study's findings. Though primarily it is for the learners' benefit, and it may also build a stronger connection between the teacher and the learner, or even between school and home. If found effective on a broader scope, such intervention might become one of the best practices of our teachers. Future researchers may also explore other strategies or variables to expand this study to make learning more meaningful to our learners.

\section{REFERENCES}

Atkinson,R. and D. Hansen (2017). Video-Assisted Instruction in students' performance:the standford project. Standford University and Florida State University's.

Bilgin,I. (2016). The effect of hands-on activities incorporating a cooperative learning approach on eight grade students' science process skills and attitudes towards science Journal of Baltric Science Education, 1 (9), 27-37.

Bloomfield, Jacqueline, and Murray J. Fisher. "Quantitative research design." Journal of the Australasian Rehabilitation Nurses Association 22, no. 2 (2019): 27-30.

Chaurdari, P. (2017). Computer assisted instruction: development of instructional strategy for biology teaching.Irso University of Vanda, India. Pp. 106.

Chen, Y. Y., Chang, Y. S., Lee, J. Y., \& Lin, M. H. (2021). Effects of a Video Featuring Connected Speech Instruction on EFL Undergraduates in Taiwan. SAGE Open, 11(2), 21582440211019746.

Hamad, S. M. S., Iqbal, S., Alothri, A. M., Alghamadi, M. A. A., \& Elhelow, M. K. K. A. (2020). "To teach is to learn twice" Added value of peer learning among medical students during COVID-19 Pandemic. MedEdPublish, 1.

Lassnigg, L. (2017). Lost in translation: learning outcomes and the governance of education. Journal of education and work, Vol. 25, No 3, pp. 299-330. http://www.tandfonline.com/doi/full/10.1080/13639080.2017.687573

Maligalig, D., and J. R. Albert. (2016). Measures for Assessing Basic Education in the Philippines. PIDS Discussion Paper Series No. 2016-16, Philippine Institute for Development Studies, Makati City.

Ogundola PI. (2016). Effects of peer tutoring strategy on academic achievement of students in technical drawing in Nigeria. British Journal of Education, Society \& Behavioral Science.19(1):1-10

Pedroso, J. E. P. (2021). School On Wheels and Multimedia-Aided Instructions as Mediators of Students 'Local Cultural Heritage Awareness. International Journal of Arts and Humanities Studies, 1(1), 63-69.

Sener, S., \& Çokçaliskan, A. (2018). An investigation between multiple intelligences and learning styles. Journal of Education and Training Studies, 6(2), 125-132.

Willingham, D. T. (2018). Ask the Cognitive Scientist: Does Tailoring Instruction to" Learning Styles" Help Students Learn?. American Educator, 42(2), 28.

Winarti, A., Yuanita, L., \& Nur, M. (2019). The Effectiveness of Multiple Intelligences Based Teaching Strategy in Enhancing the Multiple Intelligences and Science Process Skills of Junior High School Students. Journal of Technology and Science Education, 9(2), 122-135. 